Old Dominion University ODU Digital Commons

$5-2020$

\title{
A Continuum of Data Literacy for Teaching
}

Jori S. Beck

Diana Nunnaley

Follow this and additional works at: https://digitalcommons.odu.edu/teachinglearning_fac_pubs

Part of the Curriculum and Instruction Commons, Educational Assessment, Evaluation, and Research Commons, and the Teacher Education and Professional Development Commons 


\begin{abstract}
Accountability for education in the United States has existed since the first formalized system of education. Although this accountability is an important part of society, these systems must be expanded beyond high stakes assessments to include other types of data including P-12 student voices. The purpose of the current manuscript is to present a continuum for data literacy for teachers that spans preservice to inservice teacher education. We conceptualize data literacy for teachers as a metaconstruct that includes the construct of assessment literacy. The research on enabling and marginalizing factors and exposure to data are reviewed at the preservice and inservice level before a continuum of data literacy for teachers from novice through expert is presented. Implications for practice and research are explored.

Keywords: data literacy for teaching, preservice teacher education, inservice teacher education
\end{abstract}




\section{A Continuum of Data Literacy for Teaching}

Accountability for education in the United States has existed since the first formalized system of education. Teachers, often women, working in Western schools had strict guidelines governing their behavior including curfews and church attendance (Mondale \& Patton, 2002). Accountability systems have grown and changed since that time with increased focus on the academic performance of children-particularly standardized assessments — rather than the social behavior of teachers evident in the example above. Although No Child Left Behind ([NCLB], 2002) is often cited as a milestone in the accountability movement globally (Carey, Grainger, \& Christie, 2018), there were many other important events leading up to NCLB that deserve recognition as harbingers of modern accountability systems in the United States.

In particular, certain historic national events have rippled out to create waves in American education. Although it is debatable when accountability began in earnest, a few events can be identified that show the beginning of the collective focus on reforming education. The launch of Sputnik by the Soviet Union in 1957 was one such event that put a spotlight on education including building capacity for the space race (Strauss, 2017). This event and the ensuing reaction generated mistrust in American education. A Nation at Risk, the 1983 report by the American National Commission on Excellence in Education, conveyed that American schools were failing and included a call to action. This report bordered on propaganda-for example, in one instance the report compares American education to an unfriendly act by a foreign power. As intended, A Nation at Risk triggered a series of reforms-including the involvement of the business community such as Total Quality Management (Schmoker \& Wilson, 1996). The Sandia Report (Carson, Huelskamp, \& Woodall, 1992), published almost a decade later, challenged the narrow interpretation of the data in A Nation at Risk but remains 
relatively unknown compared to its popular predecessor. Yet this report demonstrated the importance of looking at data critically, holistically, and longitudinally. Indeed, even today, a narrow focus on standardized test scores remains a persistent problem in accountability systems (Mandinach \& Gummer, 2016a) and the lesson of the Sandia Report (i.e., to consider data holistically including growth over time) remains largely unheeded. These events and policies have influenced the current American accountability context.

Although the Every Student Succeeds Act ([ESSA], 2015) has provided some relief from the stringent accountability measures of NCLB (2002), the American system still privileges high-stakes test scores to the neglect of other, more robust data. These systems must be expanded beyond high stakes assessments to include other types of data such as P-12 student voices (Webber, Scott, Aitken, \& Lupart, 2014). The United States is just one country that faces this push for greater accountability and many Organisation for Economic Co-Operation and Development countries are grappling with these policies as well (Gale, Mills, \& Cross, 2017). In addition to governmental policies, an important aspect of capacity building in this goal is teacher preparation -including preservice and inservice. The purpose of the current manuscript is to present a continuum for data literacy for teachers ([DLFT], see Table 1) that spans preservice to inservice teacher education. Researchers have called for this continuum (Mandinach \& Gummer, 2016a) and a continuum has been developed for the construct of assessment literacy ([AL]; Coombs, DeLuca, LaPointe-McEwan, \& Chalas, 2018) but a continuum is still needed for DLFT. This continuum provides guidance for colleges of education, local education agencies, and professional development providers regarding how to foster DLFT across the career span of an educator. We begin by operationalizing the construct of DLFT.

\section{Ope rationalizing Data Literacy for Teachers}


We operationalize DLFT according to Gummer and Mandinach's (2015) definition, $[\mathrm{T}]$ he ability to transform information into actionable instructional knowledge and practices by collecting, analyzing, and interpreting all types of data (assessment, school climate, behavioral, snapshot, longitudinal, moment-to-moment, and so on) to help determine instructional steps. It combines an understanding of data with standards, disciplinary knowledge and practices, curricular knowledge, pedagogical content knowledge, and an understanding of how children learn. (p. 2)

Definitions of AL share similar properties including using assessments to make decisions (Alkharusi, Kazem, \& Al-Musawi, 2010) and using a variety of assessment types (Mertler, 2004). However, we position DLFT as a metaconstruct (Beck, Morgan, Riddle, Whitesides, \& Brown, under review) that includes the construct of AL. The term metaconstruct was coined by Fredricks, Blumenfeld, and Paris (2014) in their review of engagement because the metaconstruct of engagement included three components: emotional, behavioral, and cognitive. We view DLFT similarly in that it has subconstructs such as AL. This is most clearly illustrated in Mandinach and Gummer's (2013, 2016a) framework; however, Mandinach and Gummer have also demonstrated this connection empirically (2011). A wide variety of data, including behavioral and affective data, allow educators to more holistically analyze academic growth at the student and school level. Moreover, modern accountability systems are starting to recognize diverse forms of data. For example, ESSA (2015) affords states the opportunity to utilize different types of data to evaluate progress. Because students are diverse in how they learn and need a variety of options for demonstrating their understanding, it is important that teachers are well versed in how to collect a variety of data. Indeed, student engagement-including behavioral, affective, and cognitive - has been associated with student learning, grades, test 
scores, retention, and graduation (Parsons, Malloy, Ward Parsons, Peters-Burton, \& Cohen Burrowbridge, 2018). Thus, we found it most appropriate to situate our work within the concept of DLFT.

\section{Literature Review}

This review of the literature is organized according to the research on preservice teacher education and inservice teacher education to convey what the field knows about these unique career stages. Because the continuum below presents the knowledge and skills that teachers need to enact DLFT, included in this review of the topical research are contextual factors that could influence the implementation of the DLFT continuum: enabling and marginalizing factors and exposure to data. The enabling and marginalizing factors provide an overview of how to support DLFT and AL whereas the research on exposure to data elaborates on what this exposure looks like. While enabling factors and exposure to data may sometimes be the same, the enabling factors represent an "ideal" whereas the actual exposure may look different in practice which is why we considered it important to distinguish them in the review of literature below. We include research on both DLFT and AL; again, we conceptualize AL as a construct within the metaconstruct of DLFT. We indicate which construct or metaconstruct was studied in each article for clarity and to avoid problematic conflation (Mandinach \& Gummer, 2013). Finally, we included studies from around the world due to the international reach of policies for using educational data to drive educational decision making (Carey et al., 2018) which have sparked research on the topic. We begin with preservice teacher education; the literature included below was chosen based on a recent systematic review of research on DLFT and AL at the preservice level (Beck et al., under review).

\section{Preservice Teacher Education}


Enabling and marginalizing factors. Instruction in DLFT and AL at the preservice level is complicated by the context of teacher education. In the last three decades in the United States, teacher education scholars have pushed to move teacher education more deeply into schools and foster simultaneously renewing partnerships between colleges of education and school districts (National Council for the Accreditation of Teacher Education Blue Ribbon Panel, 2010; The Holmes Group, 1986). While this extended time in the field has been achieved in isolated programs (c.f., Solomon, 2009), the persistent lack of time in the field in general may make it difficult for preservice teachers (PSTs) to be exposed to authentic data and their uses. Moreover, in the United States, the Family Educational Rights and Privacy Act ([FERPA], 1974) provides guidance on which data are publicly available and which are protected. It also conveys who is allowed to access each type of data. While this is a necessary and useful measure, it can complicate PSTs' access to student data since PSTs are not teachers of record and may thus be excluded from reviewing student learning data that could be useful to their own development. Policy or guidelines are needed in the United States to translate FERPA for use in teacher preparation much like the American Association of Colleges for Teacher Education (2016) has for video recording. A follow-up to such a policy would be the incorporation of ethical data use content at the preservice level (Mandinach \& Wayman, in preparation).

Further complicating DLFT and AL in teacher education is the lack of PST autonomy. For example, in Australia Carey and colleagues (2018) noted that they were unable to evaluate PSTs' abilities to use data within school settings because PSTs were not able to make changes to the school curriculum. Thus, the inherent act of learning to teach in someone else's classroom can limit preservice DLFT instruction. This is compounded when the school-based teacher educator working with the PST has not been prepared to use data in a robust way. Mandinach 
and Gummer (2016b) studied four teacher preparation programs in depth to learn about how they prepared PSTs to use data - some of which were emerging and some of which were exemplary in their implementation of DLFT. The authors discovered several key themes in this implementation: (a) leadership and vision (i.e., for teacher preparation and data), (b) staffing and personnel (specifically, hiring former outstanding classroom teachers), (c) sustainability over time (through leadership changes; some programs also scaled up their activities), (d) use of data for continuous improvement (i.e., for the institution), (e) placement of students and relationships with districts (established relationships with partner schools), and (f) collaborating institutions (partners). Thus, it appears that faculty in teacher preparation programs who want to foster DLFT in PSTs should consider these components. Despite these limitations, research on how PSTs are prepared for thinking with and using data and assessments is emerging.

Expos ure to data. Perhaps as a result of these enabling and marginalizing factors, the research that exists on how PSTs are exposed to data, including assessments, mainly exists within teacher preparation coursework rather than field experiences. Mandinach, Friedman, and Gummer (2015) conducted a multicomponent study of schools of education and how they were preparing teachers to be data literate. They found that about two thirds of schools of education reported offering a stand-alone DLFT course. Furthermore, they found that this course is a requirement for a teaching degree, is typically offered for preservice teachers, is offered at the undergraduate level, is delivered face-to-face by a tenure-track professor, and includes components in which PSTs access and examine both authentic and simulated data. However, these courses focused on AL instead of DLFT and modern data systems (e.g., data warehouses) and data tools (e.g., student dashboards) were often not addressed. There was also confusion regarding whether licensure or certification requirements included coursework on DLFT. Indeed, 
within licensure requirements, there was a wide range of the required knowledge and skills. Thus, based on this national study, it appears that there may be incoherence in teacher preparation DLFT. In their in-depth study of four programs, Mandinach and Gummer (2016b) found that the emerging and exemplary programs that they studied included particular curricular elements of DLFT including (a) course design, (b) competencies and supports, (c) integration of skills and knowledge with pedagogical content knowledge, (d) practica, and (e) support systems for students.

Mandinach and colleagues' (2015) and Mandinach and Gummer's (2016b) studies are the only ones of their kind to explore the nature of preservice preparation for DLFT specifically. However, a number of intervention studies have provided nuance regarding how PSTs respond to instruction in how to use data and assessments including their abilities, perceptions, and selfefficacy (e.g., Kennedy et al., 2016; Reeves \& Chiang, 2018). Computer-mediated platforms have shown promise in AL interventions as well (e.g., Alkharusi et al., 2010; Wang, Wang, \& Huang, 2008; Zwick et al., 2008). Some of the DLFT interventions have been as brief as six hours (Reeves \& Honig, 2015) yet have demonstrated promise in fostering PST growth in their ability to use data to make decisions as well as their attitudes and beliefs about data. However, the studies that claim to focus on DLFT often use measures and methods that are actually better aligned to the construct of AL so these studies may suffer from incoherence. This is true of the Reeves and Chiang (2018) study that explored PSTs' anxiety and self-efficacy related to datadriven decision making. The authors used Dunn, Airola, Lo, and Garrison's (2013) survey on data-driven decision making but the instrument narrowly focused on assessments rather than a broad array of data. Although the authors used non-academic data in this study as well, the ongoing use of instruments that do not measure DLFT specifically is problematic and 
complicates what is known about how PSTs learn about data since existing studies are still focused narrowly on AL and a measure for DLFT currently does not exist.

However, much like the research on DLFT, the research on AL unequivocally demonstrates that PSTs can learn how to use assessments to drive their instruction-sometimes even outperforming their inservice peers (e.g., Alkharusi, Kazem, \& Al-Musawi, 2011). DeLuca, Chavez, and Cao (2013) investigated PSTs' confidence in and conceptions of assessments specifically. PSTs who participated in the study were enrolled in a preservice measurement course. Based on analysis of a mixed methods questionnaire, DeLuca and colleagues found that participants developed a more nuanced view of testing that included format, purpose, and process that was akin to experienced teachers. Participants' assessment confidence also increased at the end of the course. The authors advocated for the acknowledgement that PSTs can develop more complex understandings of assessment as well as skills and confidence in this domain.

Other studies have demonstrated similar PST growth in alternative assessments (Tatar \& Buldur, 2013) and formative assessment (Hamodi, Lopez-Pastor, \& Lopez-Pastor, 2017). In fact, both Tatar and Buldur's (2013) and Hamodi and colleagues' (2017) studies have demonstrated that PSTs can transfer what they learn in teacher preparation programs to their teaching.

In sum, both face-to-face and computer mediated platforms have demonstrated promise in fostering PST DLFT and AL. Indeed, it is very clear from this research that PSTs can learn nuanced information about DLFT and grow in their confidence in this metaconstruct - in some instances even demonstrating knowledge equivalent to their veteran peers. However, little research has been conducted in field experiences that approximate the work of real teachers in real classrooms which is a shortcoming of this work. Athanases, Wahleithner, and Bennett's (2012) and Reeves' (2017) studies are exceptions and do provide an initial foray into the topic. 
Moreover, preservice DLFT curriculum often does not include the data systems and data tools that school districts use (Mandinach et al., 2015).

\section{Inservice Teacher Education}

Just as preservice DLFT instruction is complicated by the context of teacher education, professional development (PD) in DLFT at the inservice level is similarly confounded by school contexts. This section of the review was developed based on research on DLFT and AL at the inservice level as well as the work of the Using Data Solutions Group (2019).

Enabling and marginalizing factors. While there are many contextual factors that enable or inhibit the development of AL and DLFT at the inservice level, it is important to note that research has demonstrated that teachers' AL is influenced by the following factors at the individual level: teachers' prior experiences, years of teaching (Crusan, Plakans, \& Gebril, 2016), and beliefs (Datnow \& Hubbard, 2015). This is a nod to the importance of teacher preparation programs, but also the need to meet individual teachers where they are in their learning and implementation of AL and, likely, DLFT. Some research has also demonstrated that teachers want PD focused on their needs (Hoogland et al., 2016) which is a testament to the importance of differentiated PD. In a study of data use across countries, Schildkamp, Karbautzki, and Vanhoof (2014) found that some teachers viewed a variety of data as useful while other teachers viewed this negatively and felt that they could become overwhelmed by too much data. It is important to understand these individual considerations which can mitigate how teachers engage with AL and DLFT.

DLFT preparation at the inservice level is complicated by larger environmental factors including incoherence in the field of DLFT and AL around constructs like formative assessment (Datnow \& Hubbard, 2015; Frey \& Schmitt, 2007). The broader policy environment and 
accountability systems also influence teachers' data use (Datnow \& Hubbard, 2015; Hoogland et al., 2016). For example, in Alberta, Canada teachers are involved in creating and scoring assessments (Daniels, Poth, Papile, \& Hutchison, 2014) which is not true of countries like the United States. Issues and policies like these can drive teachers' AL and DLFT work.

The local context within which teachers operate provides unique enabling and marginalizing factors for DLFT. Specifically, Datnow and Hubbard (2015) noted that there are multiple contexts that influence teachers' use of data at the school level including school leadership, organizational contexts, and teacher capacity for data use. In their study of teachers' use of data systems, Cho and Wayman (2014) found that how districts framed data use influenced how teachers used the data systems in the three districts that they studied. They discovered that central office staff often fell short in helping teachers make sense of data and, instead, focused on technical aspects of implementation. They also argued that data systems could be used to support teacher collaboration. Hoogland and colleagues (2016) have identified the importance of resources such as computer systems, interim assessments, and technology. However, these resources must be evaluated carefully since tests may aim to provide comparative data yet do not provide useful diagnostic data on student performance (Popham, 2008). Teachers need to be able to differentiate between data that are useful, including assessments, and those that are not. The timeliness of data is also important (Farley-Ripple \& Buttram, 2014). Teaching load has been shown to influence how teachers talk about assessment-specifically, teachers with heavier loads were more likely to talk negatively about assessment (Crusan et al., 2016). In sum, leadership at the district and building level can support or hinder teachers' implementation of DLFT but this is mitigated by teachers' prior experiences and their beliefs about DLFT. 
Expos ure to data. Within schools, DLFT is often implemented within collaborative meetings called professional learning communities ([PLCs]; c.f., Farley-Ripple \& Buttram, 2014). Indeed, research points to the importance of collaboration in data to foster teachers' DLFT (Hoogland et al., 2016; Jimerson, Garry, Poortman, \& Schildkamp, this issue; Kippers, Poortman, Schildkamp, \& Visscher, 2018; McNaughon, Lai, \& Hsiao, 2012; van Geel, Keuning, Visscher, \& Fox, 2017). In their study of PLC implementation, Farley-Ripple and Buttram (2014) found the importance of regular, consistent meeting time and access to data. School leaders were also important in the implementation of these PLCs. Their decisions about who participates, when, and how often influence the design of the organizational routine. Too frequently these decisions are based on which teachers can be covered more easily instead of deep thinking about the optimal combination of teachers and staff (Using Data Solutions, 2019). Team composition can be very different in a large urban or suburban district compared to a small or rural school. At least one model (Kippers et al., 2018) has been shown to foster collaborative data use and even teacher growth in DLFT in both the Netherlands and the U.S. (Jimerson et al., this issue).

However, teacher autonomy within PLCs is important—specifically to manage their daily meetings and co-construct their own tools (Huguet, Farrell, \& Marsh, 2017). Research has demonstrated that teachers acquire assessment knowledge through reflection on their own practice as well as through school-wide initiatives (Howley, Howley, Henning, Gillam, \& Weade, 2013). Educators who have time and support to discuss data with colleagues may also be able to implement equitable outcomes for students (Huguet et al, 2017). Extended time for teacher learning in PD has been supported by research (Opfer \& Pedder, 2011). 
The growing sophistication of Internet-based assessment and reporting applications that provide teachers continuous opportunities to monitor student growth may also be a contributing factor to (a) schools' limiting PD in data use and (b) teachers' narrowing their analysis of data to pre-packaged reports (Using Data Solutions, 2019). Users of today's technologies expect that menus, formats, and instructions follow established routines across devices, platforms, and applications. Assessment providers attempt to furnish similar user-friendly modes of operation and, by doing so, can serve to convince decision makers that little to no PD is required to use the system. The reality in most schools is that there are multiple assessment systems, each with their own access features, with data formats unique to their own system. The incompatibility of different data sources can further limit teams' analyses to just assessment results because data from student information systems, English Language Learner growth reports, and social emotional reporting require greater technological expertise requiring more, rather than less, PD. Furthermore, designers of assessment reporting systems seek to visually enhance tables and charts with highlighting to draw attention to groups of students performing at predetermined levels of achievement. Instead of teachers engaging in a thoughtful process to determine their own thresholds, teachers are frustrated by (a) not being able to find information in the report about how the thresholds were set and (b) no ability to enter their own thresholds after careful consideration of their own goals for students, school improvement plan learning goals, or statemandated growth targets. Shepard, Penuel, and Pellegrino (2018) described how opportunity is lost when measurement is narrowed in this way. All of these factors mitigate teachers' use of data.

An additional consideration is the recognition that DLFT development without cultural proficiency limits the potential for teachers discovering the extent to which their own 
backgrounds may blind them to biases informing decisions about which students get access to high-level, rigorous curriculum and instruction (Bocala \& Boudett, 2015; Love, Stiles, Mundry, \& DiRanna, 2008). Student demographic data and community economic data are rarely available to begin explorations into who stakeholders are and what they value; perhaps as a result of this limitation and others, little is known about how data can be used to ensure equity in educational improvement (Datnow, Greene, \& Gannon-Slater, 2017) although content on culturally responsive data use is in preparation (e.g., Mandinach, Warner, \& Mundry, 2020). Some research points to the importance of maintaining an asset approach to data use that focuses on the whole child (Park, St. John, Datnow, \& Choi, 2017). Garner, Thorne, and Horn (2017) explored one math teacher workgroup and described how they reduced complex constructs to make them overly simplistic, privileged remediation over instructional improvement, and enacted faith in instrument validity without criticism. At the same time, these teachers were not positioned to critique the tests. Thus, providing teachers with agency and tools for this work is critical.

\section{Continuum of Data Literacy for Teachers}

The continuum below (see Table 1) was developed based on empirical work on DLFT. Specifically, we triangulated two models of DLFT to generate the skills in the continuum (i.e., left side of the continuum): Mandinach and Gummer's DLFT conceptual framework (2016a) and the data use model from the Netherlands (Kippers et al., 2018). These two frameworks were chosen because of the authors' expertise in the field and also because the components were aligned suggesting consensus regarding the importance of these elements. Both of these frameworks included five actions that aligned to the following elements of our continuum: (a) identify issue/opportunity and set goals; (b) collect, manage, and organize high quality data; (c) transform data into information; (d) transform information into decision; and (e) evaluate 
outcome (see Table 2 for a side-by-side comparison of the two models). In presenting this continuum we do not mean to imply that the skills are discrete; indeed, upon deep reflection, we found them difficult to separate. Thus, the skills presented below may be observed in many instances as composites and overlapping. This continuum is also informed by our work with thousands of educators along their professional learning trajectory.

Not included in the continuum below are the dispositions from the DLFT framework (Mandinach \& Gummer, 2016a). We wrestled with whether to include these dispositions in Table 1; however, ultimately we decided that they were a necessary context for enactment of DLFT along the continuum presented below but not actually part of the continuum. These dispositions include: (a) belief that all students can learn, (b) belief in data/the ability to think critically, (c) belief that educational improvement is a continuous inquiry, (d) ethical use of data, (e) collaboration (including horizontal and vertical), and (f) communicating with multiple audiences.

The range of expertise represented in the continuum is based on Shulman's (1987) definitions of novice, developing, developing expert, and expert user. Moreover, Shulman conceptualized transformation as a combination of the following: preparation, representations, instructional selections, adaptations, and tailoring of instruction. These are represented in the continuum below since they provide a useful heuristic for thinking of the development of teachers' DLFT knowledge and skills as they are applied. DLFT requires the same nuances of content and pedagogical knowledge that Shulman described, and has the potential to enhance the acquisition of pedagogical content and curricular knowledge in Shulman's framework.

Novice users are described as in preparation by Shulman (1987); this is the time to build foundational knowledge and skills, and create awareness of the dispositions and beliefs needed to 
begin developing DLFT. Importantly, novice users may not understand data use beyond compliance and a deficit model. They may not be able to identify relevant and appropriate data sources, understand differences among types of data, synthesize data meaningfully, or connect data to instruction. Undergraduate courses serving as foundational preparation for becoming a teacher offer multiple opportunities for building the foundation for DLFT (e.g., foundations courses, technology courses, etc.). In the school setting, teachers in course or grade level teams, or vertical subject teams in smaller and rural school settings, can work with novice teachers to lay out their own investigations into student learning.

Developing users begin to build additional knowledge as well as confidence in using data in a structured process to inform their classroom instruction at the representation level (Shulman, 1987). These educators may be able to identify a problem of practice and some relevant data sources and stakeholders to explore this problem of practice with. They begin to make connections between data and instruction and may start to critically analyze sources of data and contextual factors. In preservice teacher education, early field experiences provide the setting for exploring FERPA as it relates to student data. As field experiences are coordinated, cooperating teachers can be sought on the basis of their own collaborative inquiry. For inservice teachers, PLCs as well as coaches can support the development of these individuals.

Developing expert users are at the instructional selections and adaptation phase (Shulman, 1987). They have established proficiency in identifying a problem of practice; collaborating with relevant stakeholders; and collecting, analyzing, and synthesizing data. They have a solid understanding of data ethics and consider a variety of contextual factors. They are able to use data to check for misconceptions. In teacher preparation programs, practica experiences and student teaching experiences all have the ideal window for introducing and 
practicing these skills. For inservice teachers, developing expert users can be supported by ongoing PD, data coaches, and PLCs.

Expert users, Shulman's (1987) adaptation and tailoring of instructions phase, are data leaders. They approach data use proactively and iteratively and support other data users in their program or building. They have a deep understanding of the data inquiry cycle and collaboration around data use. They may facilitate PLCs or lead other data efforts at the program or building level. They have a wide repertoire of pedagogical strategies to employ based on data and have a deep understanding of data ethics and contextual factors. Expert users at the preservice level can be supported through extended field experiences such as student teaching or the residency year. At the inservice level, expert users are teacher leaders.

\section{Limitations}

We present this continuum as a potential path forward for researching and developing DLFT in new, novice, and veteran teachers. The continuum presented below represents these as discrete skills but this is not the nature of DLFT which is a composite of these (often overlapping) skills. Although this continuum is based on empirical research (Kippers et al., 2018; Mandinach \& Gummer, 2016a), it would benefit from validation and we encourage other researchers to explore this. The continuum developed for AL across different career stages (Coombs et al., 2018) may be useful for future researchers to consider in this undertaking. The continuum, although an initial foray, is necessary for practice, data literacy preparation, and research — particularly to develop measures to gauge improvement in DLFT.

\section{Dis cussion}

Traditional teacher preparation programs housed in institutions of higher education are now just one path to licensure. These exist alongside alternative route programs that have 
experienced as much as a 40\% increase in enrollment in 2010-2018 in the United States while traditional programs have seen a corresponding decline in enrollment by about one third nationally (Partelow, 2019). This landscape between traditional and alternative routes to licensure is muddied by innovative programs like teacher residencies that provide extended field experiences while simultaneously attracting more diverse candidates and reducing barriers to licensure like alternative route programs. Thus, the field of teacher education is diverse and sprawling.

This context is important because the continuum provided here includes the categories of novice, developing, developing expert, and expert user. These categories will not line up neatly with new PSTs nor experienced veteran teachers due to the variety of paths to licensure which education professionals can now take. Moreover, a brand new PST may come to a program with experience as a paraprofessional or substitute teacher that can slide them up or down this continuum. Thus, as with any learner, this continuum should be considered in light of users' previous experiences and knowledge. Moreover, this continuum should not be taken as finite; teaching is an ongoing journey and each new group of students will have different needs that teachers must respond to. Thus, we recommend that teachers constantly reflect on classroomand building-level evidence to improve their practice-especially with colleagues.

At the preservice level, this review of the literature and corresponding continuum present several opportunities for research and development. More needs to be learned about how field experiences can support PST DLFT. In addition to validating the current continuum, a continuum for practice also needs to be created and validated. This continuum could begin with the earliest field experiences and include a corresponding menu of assignments and activities to support proficiency with data like the one that has been established for research-based teacher 
education in Norway (Smith, 2017). Contextualizing this to each program and setting will be important. Additionally, DLFT content must be incorporated into initial teacher preparation coursework to establish a foundation for learning in this domain-including building off of prior knowledge and experiences. Additional research and curricula are also needed to prepare PSTs to collaborate around data use. The traditional student teaching experience or residency year are ideal spaces within field experiences for this work.

At the inservice level, studies have focused on teachers' implementation of prescriptive programs and practices and many of those studies have highlighted features of implementation and practices that worked in specific settings. Due to the very complex interplay of both internal and external factors supporting or inhibiting change from within school communities, studies have often fallen short of revealing key factors required to achieve and sustain continuous improvement. More needs to be learned about the nexus of individual teacher learning, teambased continuous collaborative inquiry, and the contextual elements associated with continued growth. Additionally, what is less well understood are the factors enabling teachers to begin to question their own internal biases and understandings about students' abilities. In Mandinach and Gummer's (2016a) framework, there is a category of components entitled, "Dispositions, habits of mind, or factors that influence data use" (p. 372) that is presented as an overall approach or way of being. This area is ripe for research and sorely needed. When and under what circumstances do teachers individually and collectively shift from using data to confirm their own assumptions and mental models to challenging long-held expectations for student learning that result in more rigorous classroom instruction and dialogue? This is critical as public schools grow increasingly diverse. 


\section{References}

Alkharusi, H., Kazem, A. M., \& Al-Musawai, A. (2010). Traditional versus computer-mediated approaches of teaching educational measurement. Journal of Instructional Psychology, 37(2), 99-111.

Alkharusi, H., Kazem, A. M., \& Al-Musawai, A. (2011). Knowledge, skills, and attitudes of preservice and inservice teachers in educational measurement. Asia-Pacific Journal of Teacher Education, 39(2), 113-123. doi:10.1080/1359866X.2011.560649

American Association of Colleges for Teacher Education. (2016). Securing personal information in performance assessment of teacher candidates. Author: Washington D.C. Retrieved from https://secure.aacte.org/apps/r1/res_get.php?fid=2538\&ref=r1

Athanases, S. Z., Wahleithner, J. M., \& Bennett, L. H. (2012). Learning to attend to culturally and linguistically diverse learners through teacher inquiry in teacher education. Teachers College Record, 114, 1-50. Retrieved from www.tcrecord.org

Beck, J. S., Morgan, J. J., Riddle, D. R., Whitesides, H., \& Brown, N. (under review). Finding coherence: A review of assessment literacy and data literacy for teaching.

Bocala, C., \& Boudett, K. P. (2015). Teaching educators habits of mind for using data wisely. Teachers College Record, 117(4), 1-20. Retrieved from www.tcrecord.org

Carey, M., Grainger, P., \& Christie, M. (2018). Preparing preservice teachers to be data literate: A Queensland case study. Asia-Pacific Journal of Teacher Education, 46(3), 267-278. doi:10.1080/1359866X.2017.1402860

Carson, C. C., Huelskamp, R. M., \& Woodall, T. D. (1992). Perspectives on education in America: An annotated briefing. Journal of Educational Research, 86(5), 259-265. Retrieved from http://www.jstor.org/stable/27541876 
Cho, V., \& Wayman, J. C. (2014). Districts' efforts for data use and computer data systems: The role of sensemaking in system use and implementation. Teachers College Record, 116(2), 1-45. Retrieved from www.tcrecord.org

Coombs, A., DeLuca, C., LaPointe-McEwan, D., \& Chalas, A. (2018). Changing approaches to classroom assessment: An empirical study across teacher career stages. Teaching and Teacher Education, 71, 134-144. doi:10.1016/j.tate.2017.12.010.

Crusan, D., Plakans, L., \& Gebril, A. (2016). Writing assessment literacy: Surveying second language teachers' knowledge, beliefs, and practices. Assessing Writing, 28, 43-56. http://dx.doi.org/10.1016/j.asw.2016.03.001

Daniels, L. M., Poth, C., Papile, C., \& Hutchison, M. (2014). Validating the conceptions of Assessment-III Scale in Canadian preservice teachers. Educational Assessment, 19(2), 139-158. doi:10.1080/10627197.2014.903654.

Datnow, A., Greene, J., \& Gannon-Slater, N. (2017). Data use for equity: Implications for teaching, leadership, and policy. Journal of Educational Administration, 55(4), 354-360. https://doi.org/10.1108/JEA-04-2017-0040

Datnow, A., \& Hubbard, L. (2015). Teachers' use of assessment data to inform instruction: Lessons from the past and prospects for the future. Teachers College Record, 117, 1-26. Retrieved from www.tcrecord.org

DeLuca, C., Chavez, T, \& Cao, C. (2013). Establishing a foundation for valid teacher judgement on student learning: The role of pre-service assessment education. Assessment in Education: Principles, Policy \& Practice, 20(1), 107-126. doi:10.1080/0969594X.2012.668870 
Dunn, K. E., Airola, D. T., Lo, W.-J., \& Garrison, M. (2013). Becoming data driven: The influence of teachers' sense of efficacy on concerns related to data-driven decision making. Journal of Experimental Education, 81 (2), 222-241.

Every Student Succeeds Act. Public law 114-95. (2015).

Family Educational Rights and Privacy Act of 1974, 20 U.S.C. § 1232g (1974).

Farley-Ripple, E. N., \& Buttram, J. L. (2014). Developing collaborative data use through professional learning communities: Early lessons from Delaware. Studies in Educational Evaluation, 42,41-53. Retrieved from http:/dx.doi.org/10.1016/j.stueduc.2013.09.006

Fredricks, J. A., Blumenfeld, P. C., \& Paris, A. H. (2004). School engagement: Potential of the concept, state of the evidence. Review of Educational Research, 74(1), 59-109.

Frey, B. B., \& Schmitt, V. L. (2007). Coming to terms with classroom assessment. Journal of Advanced Academics, 18(3), 402-423.

Gale, T., Mills, C., \& Cross, R. (2017). Socially inclusive teaching: Belief, design, action as pedagogic work. Journal of Teacher Education, 68(3), 345-356. doi:10.1177/0022487116685754

Garner, B., Thorne, J. K., \& Horn, I. S. (2017). Teachers interpreting data for instructional decisions: Where does equity come in? Journal of Educational Administration, 55(4), 407-426. https://doi. org/10.1108/JEA-09-2016-0106

Gummer, E. S., \& Mandinach, E. B. (2015). Building a conceptual framework for data literacy. Teachers College Record, 117(4), 1-22. Retrieved from www.tcrecord.org.

Hamilton, L., Halverson, R., Jackson, S. S., Mandinach, E., Supovitz, J. A., \& Wayman, J. C. (2009). Using student achievement data to support instructional decision making. NCEE 2009-4067 U.S. Department of Education. Retrieved from 
http://ies.ed.gov/ncee/wwc/pdf/practice_guides/dddm_pg_092909.pdf

Hamodi, C., Lopez-Pastor, V. M., \& Lopez-Pastor, A. T. (2017). If I experience formative assessment whilst studying at university, will I put it into practice later as a teacher? Formative and shared assessment in initial teacher education (ITE). European Journal of Teacher Education, 40(2),171-190. http://dx.doi.org/10.1080/02619768.2017.1281909

Hoogland, I., Schildkamp, K., van der Kleij, F., Heitink, M., Kippers, W., Veldkamp, B., \& Dijkstra, A. M. (2016). Prerequisites for data-based decision making in the classroom: Research evidence and practical illustrations. Teaching and Teacher Education, 60, 377386. http://dx.doi.org/10.1016/j.tate.2016.07.012

Howley, M. D., Howley, A., Henning, J. E., Gillam, M. B., \& Weade, G. (2013). Intersecting domains of assessment knowledge: School typologies based on interviews with secondary teachers. Educational Assessment, 18, 26-48. doi:10.1080/10627197.2013.761527

Huguet, A., Farrell, C. C., \& Marsh, J. A. (2017). Light touch, heavy hand: Principals and datause PLCs. Journal of Educational Administration, 55(4), 376-389. https://doi.org/10.1108/JEA-09-2016-0101

Jimerson, J., Garry, V., Poortman, C., \& Schildkamp, K. (this issue). Implementation of a collaborative data use model in a United States context.

Kennedy, M. J., Wagner, D., Stegall, J., Lembke, E., Miciak, J., Alves, K. D...Hirsch, S. E. (2016). Using content acquisition podcasts to improve teacher candidate knowledge of curriculum-based measurement. Exceptional Children, 82(3), 303-320. doi:10.1177/0014402915615885 
Kippers, W. B., Poortman, C. L., Schildkamp, K., \& Visscher, A. J. (2018). Data literacy: What do educators learn and struggle with during a data use intervention? Studies in Educational Evaluation, 56, 21-31. https://doi.org/10.1016/j.stue duc.2017.11.001

Love, N., Stiles, K. E., Mundry, S., \& DiRanna, K. (2008), The data coach's guide to improving learning for all students; Unleashing the power of collaborative inquiry. Thousand Oaks, CA: Corwin Press.

Mandinach, E. B., Friedman, J. M., \& Gummer, E. S. (2015). How can schools of education help to build educators' capacity to use data? A systematic review of the issue. Teachers College Record, 117(4), 1-50. Retrieved from http://www.tcrecord.org.

Mandinach, E. B., \& Gummer, E. S. (2011). The complexities of integrating data-driven decision making into professional preparation in schools of education: It's harder than you think. Alexandria, VA, Portland, OR, and Washington, DC: CNA Education, Education Northwest, and WestEd.

Mandinach, E. B., \& Gummer, E. S. (2013). Defining data literacy: A report on a convening of experts. Journal of Educational Research and Policy Studies, 13(2), 6-28.

Mandinach, E. B., \& Gummer, E. S. (2016a). What does it mean for teachers to be data literate: Laying out the skills knowledge and dispositions. Teaching and Teacher Education, 60, 366-376. doi:10.1016/j.tate.2016.07.011

Mandinach, E. B., \& Gummer, E. S. (2016b). Data literacy for educators: Making it count in teacher preparation and practice. New York, NY and San Francisco, CA: Teachers College Press and WestEd.

Mandinach, E. B., Warner, S., \& Mundry, S. E. (2020, April). Using data to promote culturally responsive teaching (webinar). Regional Educational Laboratory Northeast \& Islands. 
Mandinach, E. B., \& Wayman, J. C. (in preparation). Materials to teach data ethics in teacher preparation programs. San Francisco, CA: WestEd.

McNaughton, S., Lai, M. K., \& Hsiao, S. (2012). Testing the effectiveness of an intervention model based on data use: A replication series across clusters of schools. School Effectiveness and School Improvement, 23(2), 203-228. http://dx.doi.org/10.1080/09243453.2011.652126

Mertler, C. A. (2004). Secondary teachers' assessment literacy: Does classroom experience make a difference? American Secondary Education, 33(1), 49-64.

Mondale, S., \& Patton, S. B. (Eds.). (2002). School: The story of American public education. Boston, MA: Beacon Press.

National Commission on Excellence in Education. (1983). A nation at risk: The imperative for educational reform: A report to the nation and the Secretary of Education. United States Department of Education. Washington, D.C.: Author.

National Council for the Accreditation of Teacher Education Blue Ribbon Panel on Clinical Preparation and Partnership for Improved Student Learning (2010). Transforming teacher education throughclinical practice: A national strategy to prepare effective teachers. Washington, D. C.: Author. Retrieved from http:/caepnet.org/ /media/Files/caep/accreditation-resources/blue-ribbon-panel.pdf

No Child Left Behind Act of 2001, P. L. 107-110, 20 U.S.C.§ 6319 (2002).

Opfer, V. D., \& Pedder, D. (2011). Conceptualizing teacher professional learning. Review of Educational Research, 81(3), 376-407. https://doi.org/10.3102/0034654311413609

Park, V., St. John, E., Datnow, A, \& Choi, B. (2017). The balancing act: Student classroom placement routines and the uses of data in elementary schools. Journal of Educational 
Administration, 55(4), 390-406. https://doi.org/10.1108/JEA-09-2016-0098

Parsons, S. A., Malloy, J. A., Parsons, A. W., Peters-Burton, E. E., \& Burrowbridge, S. C. (2018). Sixth-grade students' engagement in academic tasks. The Journal of Educational Research, 111 (2), 232-245. https://doi.org/10.1080/00220671.2016.1246408

Partelow, L. (2019). What to make of declining enrollment in teacher preparation programs. Washington D.C.: Center for American Progress. Retrieved from WWW.americanprogress.org.

Popham, W. J. (2008). Anchoring down the data. Educational Leadership, 66(4), 85-86. Retrieved from http://www.ascd.org/publications/educationalleadership/dec08/vol66/num04/Anchoring-Dow n-the-Data.aspx

Reeves, T. D. (2017). Pre-service teachers' data use opportunities during student teaching. Teaching and Teacher Education, 63, 263-273. http:/dx.doi.org/10.1016/j.tate.2017.01.003

Reeves, T. D., \& Chiang, J.-L. (2018). Online interventions to promote teacher data-driven decision making: Optimizing design to maximize impact. Studies in Educational Evaluation, 59, 256-269. https://doi.org/10.1016/j.stueduc.2018.09.006

Reeves, T. D., \& Honig, S. L. (2015). A classroom data literacy intervention for pre-service teachers. Teaching and Teacher Education, 50, 90-101. doi:10.1016/j.tate.2015.05.007

Schildkamp, K., Karbautzki, L., \& Vanhoof, J. (2014). Exploring data use practices around Europe: Identifying enablers and barriers. Studies in Educational Evaluation 42, 15-24. Retrieved from http://dx.doi.org/10.1016/j.stueduc.2013.10.007

Schmoker, M., \& Wilson, R. (1996). Results: The key to renewal. Educational Leadership, 52(7), 62-64. 
Shepard, L. A., Penuel, W. R. \& Pellegrino, J. W. (2018). Classroom assessment principles to support learning and avoid the harms of testing. Educational Measurement: Issues and Practice,37(1), 52-57.

Shulman, L. (1987). Knowledge and teaching: Foundations of the new reform. Harvard Educational Review, 57(1), 1-22.

Smith, K. (2017, September). Moving beyond rhetoric: Building a culture to substantiate research based teacher education. Keynote presented at the $17^{\text {th }}$ Biennial European Association of Research on Learning and Instruction Conference, Tampere, Finland.

Solomon, J. (2009). The Boston Teacher Residency: District-based teacher education. Journal of Teacher Education, 60(5), 478-488. doi:10.1177/0022487109349915

Strauss, V. (2017, April 27). Is there really a link between test scores and America's economic future? The Washington Post. Retrieved from https://www.washingtonpost.com/news/answer-sheet/wp/2017/04/27/is-there-really-alink-between-test-scores-and-americas-economic-future/

Tatar, N., \& Buldur, S. (2013). Improving preservice science teachers' self-efficacy about the use of alternative assessment: Implication for theory and practice. Journal of Baltic Science Education, 12(4), 452-464.

The Holmes Group. (1986). Tomorrow's teacher: A report of The Holmes Group. East Lansing, MI: Author.

Using Data Solutions. (2019). Home page. Retrieved from. http:/www.usingdatasolutions.org/ Van Geel, M., Keuning, T., Visscher, A., \& Fox, J.-P. (2017). Changes in educators data literacy during a data-based decision making intervention. Teaching and Teacher Education, 64, 187-198. http://dx.doi. org/10.1016/j.tate.2017.02.015 
Wang, T-Z., Wang, K-H., \& Huang, S-C. (2008). Designing a web-based assessment environment for improving pre-service teacher assessment literacy. Computers and Education, 51,448-462. doi:10.1016/j.compedu.2007.06.010

Webber, C., Scott, S., Aitken, N., \& Lupart, J. (2014). Challenges to leading fair student assessment. ISEA, 42(3), 69-84.

Zwick, R., Sklar, J. C., Wakefield, G., Hamilton, C., Norman, A., \& Folsom, D. (Summer 2008). Instructional tools in Educational Measurement and Statistics (ITEMS) for school personnel: Evaluation of three web-based training modules. Educational Measurement: Issues and Practice, 27(2), 14-27. 
Table 1

Continuum of Data Literacy for Teaching

\begin{tabular}{|c|c|c|c|c|}
\hline Component & $\begin{array}{l}\text { Novice User } \\
\text { (Shulman: } \\
\text { Preparation) }\end{array}$ & $\begin{array}{l}\text { Developing User } \\
\text { (Shulman: } \\
\text { Representation) }\end{array}$ & $\begin{array}{l}\text { Developing Expert } \\
\text { User } \\
\text { (Shulman: } \\
\text { Instructional } \\
\text { Selections \& } \\
\text { Adaptation) }\end{array}$ & $\begin{array}{l}\text { Expert User } \\
\text { (Shulman: } \\
\text { Adaptation and } \\
\text { Tailoring of } \\
\text { Instructions) }\end{array}$ \\
\hline $\begin{array}{l}\text { Identify } \\
\text { Issue/Opportunity } \\
\text { and Set Goals }\end{array}$ & $\begin{array}{l}\text { Recognize there is } \\
\text { an issue. }\end{array}$ & $\begin{array}{l}\text { Correctly identify } \\
\text { the issue, } \\
\text { potentially with } \\
\text { the assistance of } \\
\text { relevant } \\
\text { stakeholders. } \\
\text { Recognize there } \\
\text { might be some } \\
\text { mitigating } \\
\text { contextual factors } \\
\text { at the student } \\
\text { and/or school } \\
\text { level. Set a goal } \\
\text { that may or may } \\
\text { not be specific or } \\
\text { achievable. }\end{array}$ & $\begin{array}{l}\text { Correctly identify } \\
\text { the issue. } \\
\text { Involve relevant } \\
\text { stakeholders. } \\
\text { Go more in-depth } \\
\text { with the mitigating } \\
\text { contextual factors } \\
\text { at the student } \\
\text { and/or school } \\
\text { level. } \\
\text { Set a goal that is } \\
\text { specific and } \\
\text { achievable. }\end{array}$ & $\begin{array}{l}\text { Identify the } \\
\text { situation. } \\
\text { Understand the } \\
\text { context of the } \\
\text { student. } \\
\text { Understand the } \\
\text { overarching } \\
\text { situational context. } \\
\text { Involve } \\
\text { stakeholders as } \\
\text { appropriate while } \\
\text { protecting student } \\
\text { privacy. } \\
\text { Set a goal at the } \\
\text { classroom or } \\
\text { building level that } \\
\text { is specific and } \\
\text { achievable. }\end{array}$ \\
\hline $\begin{array}{l}\text { Collect, Manage, } \\
\text { and Organize High } \\
\text { Quality Data }\end{array}$ & $\begin{array}{l}\text { Unable to identify } \\
\text { relevant and } \\
\text { appropriate data } \\
\text { sources. }\end{array}$ & $\begin{array}{l}\text { Able to identify } \\
\text { some relevant and } \\
\text { appropriate data } \\
\text { sources. }\end{array}$ & $\begin{array}{l}\text { Can identify most } \\
\text { relevant and } \\
\text { appropriate data } \\
\text { sources. }\end{array}$ & $\begin{array}{l}\text { Can identify } \\
\text { relevant and } \\
\text { appropriate data } \\
\text { sources. }\end{array}$ \\
\hline
\end{tabular}




\begin{tabular}{|c|c|c|c|c|}
\hline & $\begin{array}{l}\text { Does not use } \\
\text { multiple and } \\
\text { diverse data } \\
\text { sources. } \\
\text { Fails to understand } \\
\text { the differences } \\
\text { among forms of } \\
\text { assessment and } \\
\text { their uses. } \\
\text { Does not recognize } \\
\text { good from bad } \\
\text { data as well as } \\
\text { different types of } \\
\text { data. } \\
\text { Is unable to access } \\
\text { data from } \\
\text { technologies to } \\
\text { support data use. } \\
\text { Does not know } \\
\text { how to organize } \\
\text { and ethically } \\
\text { manage data. }\end{array}$ & $\begin{array}{l}\text { Begins to use more } \\
\text { diverse data } \\
\text { sources. } \\
\text { Has a basic } \\
\text { understanding of } \\
\text { the differences } \\
\text { among forms of } \\
\text { assessment and } \\
\text { their uses. } \\
\text { Begins to } \\
\text { recognize good } \\
\text { from bad data as } \\
\text { well as different } \\
\text { types of data. } \\
\text { Knows to access } \\
\text { data from } \\
\text { technologies to } \\
\text { support data use. } \\
\text { Starts to } \\
\text { understand how to } \\
\text { organize and } \\
\text { ethically manage } \\
\text { data. }\end{array}$ & $\begin{array}{l}\text { Uses more diverse } \\
\text { data sources. } \\
\text { Has an } \\
\text { understanding of } \\
\text { the differences } \\
\text { among forms of } \\
\text { assessment and } \\
\text { their uses. } \\
\text { Can recognize } \\
\text { good from bad } \\
\text { data as well as } \\
\text { different types of } \\
\text { data. } \\
\text { Becomes more } \\
\text { sophisticated at } \\
\text { accessing data } \\
\text { from different } \\
\text { kinds of } \\
\text { technologies to } \\
\text { support data use. } \\
\text { Can organize and } \\
\text { ethically manage } \\
\text { data. }\end{array}$ & $\begin{array}{l}\text { Knows to use } \\
\text { diverse data } \\
\text { sources. } \\
\text { Has an in-depth } \\
\text { understanding of } \\
\text { the differences } \\
\text { among forms of } \\
\text { assessment and } \\
\text { their uses. } \\
\text { Can recognize } \\
\text { aspects of good } \\
\text { and bad data } \\
\text { quality (including } \\
\text { validity) as well as } \\
\text { different types of } \\
\text { data. } \\
\text { Sophisticated at } \\
\text { accessing data } \\
\text { from different } \\
\text { kinds of } \\
\text { technologies to } \\
\text { support data use. } \\
\text { Can organize and } \\
\text { manage data, } \\
\text { knowing the } \\
\text { importance of } \\
\text { ethical and } \\
\text { responsible } \\
\text { protection of data. }\end{array}$ \\
\hline $\begin{array}{l}\text { Transform Data into } \\
\text { Information }\end{array}$ & $\begin{array}{l}\text { Lacking in the } \\
\text { ability to examine } \\
\text { and analyze data. }\end{array}$ & $\begin{array}{l}\text { Nascent ability to } \\
\text { examine and } \\
\text { analyze data. }\end{array}$ & $\begin{array}{l}\text { Moderate } \\
\text { proficiency to } \\
\text { examine and }\end{array}$ & $\begin{array}{l}\text { Proficient at } \\
\text { examining and } \\
\text { analyzing data. }\end{array}$ \\
\hline
\end{tabular}




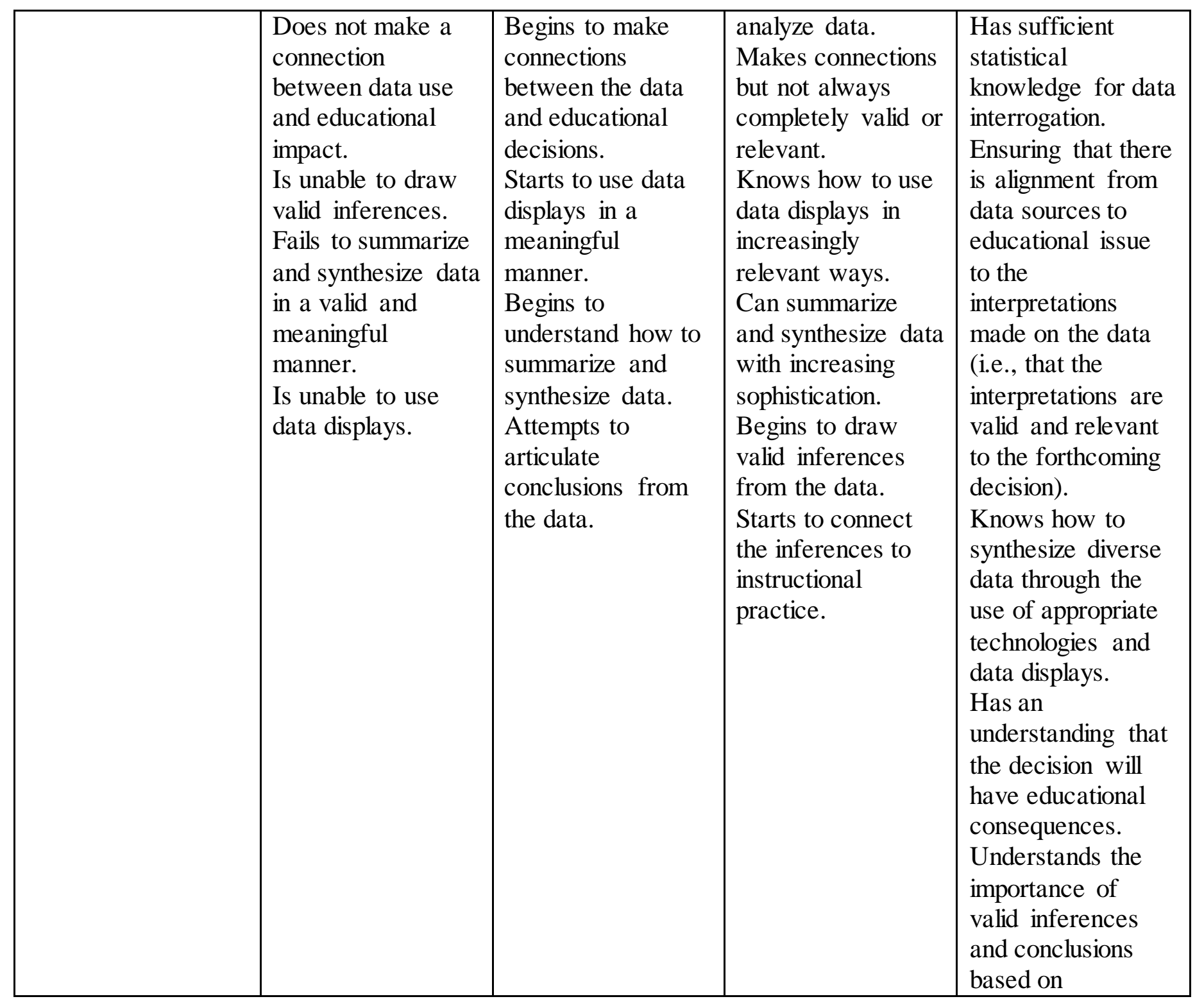




\begin{tabular}{|c|c|c|c|c|}
\hline & & & & $\begin{array}{l}\text { appropriate data } \\
\text { sources. }\end{array}$ \\
\hline $\begin{array}{l}\text { Transform } \\
\text { Information into } \\
\text { Decision }\end{array}$ & $\begin{array}{l}\text { Fails to understand } \\
\text { what the student } \\
\text { needs. } \\
\text { Fails to take into } \\
\text { consideration the } \\
\text { context. } \\
\text { Is unable to } \\
\text { determine } \\
\text { appropriate } \\
\text { instructional steps } \\
\text { based on the use of } \\
\text { data. } \\
\text { Fails to use the } \\
\text { data from which to } \\
\text { make instructional } \\
\text { decisions. } \\
\text { Takes a limited } \\
\text { view of what data } \\
\text { are relevant to the } \\
\text { instructional } \\
\text { determination. }\end{array}$ & $\begin{array}{l}\text { Begins to } \\
\text { understand what } \\
\text { the student needs. } \\
\text { Starts to take into } \\
\text { consideration the } \\
\text { context. } \\
\text { Becomes more } \\
\text { adept at } \\
\text { determining } \\
\text { appropriate } \\
\text { instructional steps } \\
\text { based on the use of } \\
\text { data including } \\
\text { moving beyond } \\
\text { reteaching. } \\
\text { Begins to use the } \\
\text { data from which to } \\
\text { make instructional. } \\
\text { decisions } \\
\text { Shows a broader } \\
\text { view of what data } \\
\text { are relevant to the } \\
\text { decision. }\end{array}$ & $\begin{array}{l}\text { Understands more } \\
\text { fully what the } \\
\text { student needs. } \\
\text { Takes into } \\
\text { consideration some } \\
\text { of the context. } \\
\text { Uses diverse data } \\
\text { in determining } \\
\text { somewhat varied } \\
\text { instructional steps. } \\
\text { Broadens their } \\
\text { view of what data } \\
\text { are relevant to the } \\
\text { decision. }\end{array}$ & $\begin{array}{l}\text { Fully understands } \\
\text { a wide range of } \\
\text { pedagogical } \\
\text { options based on } \\
\text { the diverse use of } \\
\text { data from multiple } \\
\text { sources and the } \\
\text { context of the } \\
\text { learner and } \\
\text { intended content. } \\
\text { Understands what } \\
\text { the trajectory of } \\
\text { student learning } \\
\text { might look like and } \\
\text { the needed variety } \\
\text { of instructional } \\
\text { steps within that } \\
\text { trajectory. } \\
\text { Makes appropriate } \\
\text { content-based } \\
\text { instructional } \\
\text { adjustments based } \\
\text { on the data and } \\
\text { with the right level } \\
\text { of granularity. } \\
\text { Takes into } \\
\text { consideration the } \\
\text { context of the } \\
\text { learner and } \\
\text { classroom when } \\
\text { making the }\end{array}$ \\
\hline
\end{tabular}




\begin{tabular}{|l|l|l|l|l|}
\hline Evaluate Outcome & $\begin{array}{l}\text { Assumes a } \\
\text { decision is final } \\
\text { and that there is no } \\
\text { need for follow up } \\
\text { or the iterative } \\
\text { cycle of inquiry. }\end{array}$ & $\begin{array}{l}\text { Makes a decision } \\
\text { based on } \\
\text { superficial } \\
\text { knowledge of the } \\
\text { original goal. } \\
\text { Monitors teacher } \\
\text { and student } \\
\text { performance } \\
\text { superficially. } \\
\text { Limited level of } \\
\text { introspection on } \\
\text { goals. }\end{array}$ & $\begin{array}{l}\text { Makes a decision } \\
\text { and returns to } \\
\text { consider the } \\
\text { original goal. } \\
\text { Makes some } \\
\text { comparison about } \\
\text { pre- and post- } \\
\text { outcomes. } \\
\text { May start another } \\
\text { decision cycle and } \\
\text { set another goal. }\end{array}$ & $\begin{array}{l}\text { Makes a decision } \\
\text { and definitely } \\
\text { returns to the } \\
\text { original goal. } \\
\text { Compares a robust } \\
\text { amount of pre- } \\
\text { /post- data. } \\
\text { Introspects about } \\
\text { and monitors } \\
\text { teacher and student } \\
\text { performance. } \\
\text { Recognizes the } \\
\text { importance of } \\
\text { iterations on the } \\
\text { question to } \\
\text { continuously } \\
\text { monitor the } \\
\text { intended outcomes. }\end{array}$ \\
\hline
\end{tabular}


Table 2

Side-by-Side Comparison of Data Literacy for Teachers Framework and Data Use Model

\begin{tabular}{lll}
\hline Conceptual Framework for Data Literacy for & & Data Use Model (Kippers et al., 2018) \\
\cline { 1 - 1 } Teachers (Mandinach \& Gummer, 2016a) & & Set a Purpose \\
Identify Problems/Frame Questions & Collect Data \\
Use Data & Analyze Data \\
Transform Data Into Information & Interpret Data \\
Transform Information Into Decision & Take Instructional Action \\
Evaluate Outcomes & \\
\hline
\end{tabular}

